\section{artelogie}

\section{Artelogie}

Recherche sur les arts, le patrimoine et la littérature de l'Amérique latine

\section{9 | 2016}

Horizons et perspectives de la culture en Colombie (1990-2015)

\title{
Entretien avec Renato Janine Ribeiro
}

\section{Gaspar Paz}

\section{(2) OpenEdition}

\section{Journals}

Édition électronique

URL : http://journals.openedition.org/artelogie/946

DOI : 10.4000/artelogie.946

ISSN : 2115-6395

\section{Éditeur}

Association ESCAL

Référence électronique

Gaspar Paz, «Entretien avec Renato Janine Ribeiro », Artelogie [En ligne], 9 | 2016, mis en ligne le 20 juin 2016, consulté le 18 novembre 2020. URL : http://journals.openedition.org/artelogie/946 ; DOI : https://doi.org/10.4000/artelogie.946

Ce document a été généré automatiquement le 18 novembre 2020.

Association ESCAL 


\title{
Entretien avec Renato Janine Ribeiro
}

\author{
Gaspar Paz
}

1 Renato Janine Ribeiro est docteur en philosophie et professeur d'éthique et de philosophie politique à l'Université de São Paulo. Connu et respecté pour utiliser des nouvelles pratiques politiquespédagogiques qui valorisent le dialogue et la formation de consensus, il a réaffirmé ces qualités lors de son actuation comme

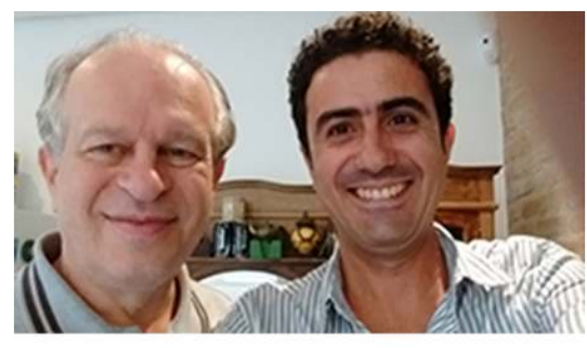
Directeur d'évaluation de la CAPES et, plus récemment, comme Ministre de l'Éducation. Il a publié, parmi d'autres livres, Ao Leitor sem Medo. Hobbes escrevendo contra o seu Tempo, Belo Horizonte, Ed. UFMG, 1999 et A Marca do Leviatã - Linguagem e Poder em Hobbes, São Paulo, Ática, 2003. Dans cet entretien, Renato Janine Ribeiro parle de la transgression dans les arts et sa relation avec l'éthique, l'esthétique, la morale et la politique. À partir des œuvres comme celles de Gustave Flaubert, Antonin Artaud, Marina Abramovic, Guimarães Rosa et le théâtre brésilien de la décennie de 1960, l'auteur souligne l'importance de la transgression dans son âge d'or (de 1850 aux milieux du xxe siècle). Ensuite, il traite de la difficulté et des limitations de l'acte transgressif aujourd'hui, dans un scénario où l'innovation et la rupture sont institutionnalisées. Dans ce sens, selon le philosophe, l'art n'est plus une question de vie ou mort, comme il a été à l'époque de Antonin Artaud ou pendant les dictatures militaires du xxe siècle. Finalement, Renato Janine Ribeiro parle du moment actuel de la politique brésilienne et des principaux défis dans les champs de l'éducation et de la culture.

2 Entretien réalisé par Gaspar Paz le 11 mars 2016, dans la résidence du philosophe Renato Janine Ribeiro à Sao Paulo. L'audio a été édité par Daniel Tápia dans le studio d'enregistrement du Centre des Arts de la UFES. 
Entretien avec Renato Janine Ribeiro - Partie 1 (MP3 - 91.2 Mo): L'âge d'or de la transgression et sa relation avec l'éthique et la politique

Entretien avec Renato Janine Ribeiro - Partie 2 (MP3 - 94.4 Mo): La transgression dans l'art contemporain

Entretien avec Renato Janine Ribeiro - Partie 3 (MP3 - 73.1 Mo): Les défis de la culture et de l'éducation dans l'actuel scénario politique brésilien 